\title{
Etiologic distribution and clinical characteristics of pediatric diabetes in 276 children and adolescents with diabetes at a single academic center
}

\author{
Ja Hye Kim, Yena Lee ${ }^{1}$, Yunha Choi ${ }^{1}$, Gu-Hwan Kim², Han-Wook Yoo ${ }^{1}$ and Jin-Ho Choi ${ }^{1 *}$ (D)
}

\begin{abstract}
Background: The prevalence of monogenic diabetes is estimated to be 1.1-6.3\% of patients with diabetes mellitus (DM) in Europe. The overlapping clinical features of various forms of diabetes make differential diagnosis challenging. Therefore, this study investigated the etiologic distribution and clinical characteristics of pediatric diabetes, including monogenic diabetes, who presented at a single tertiary center over the last 20 years.

Methods: This study included 276 consecutive patients with DM diagnosed before 18 years of age from January 2000 to December 2019 in Korea. Clinical features, biochemical findings, $\beta$-cell autoantibodies, and molecular characteristics were reviewed retrospectively.

Results: Of the 276 patients, 206 patients (74.6\%), 49 patients (17.8\%), and 21 patients (7.6\%) were diagnosed with type $1 \mathrm{DM}$, type $2 \mathrm{DM}$, and clinically suspected monogenic diabetes, respectively. Among 21 patients suspected to have monogenic diabetes, 8 patients had clinical maturity-onset diabetes of the young (MODY), and the remaining 13 patients had other types of monogenic diabetes. Among them, genetic etiologies were identified in 14 patients (5.1\%) from 13 families, which included MODY 5, transient neonatal DM, developmental delay, epilepsy, and neonatal diabetes (DEND) syndrome, Wolfram syndrome, Donohue syndrome, immune dysregulation, polyendocrinopathy, enteropathy, X-linked (IPEX) syndrome, Fanconi-Bickel syndrome, Wolcott-Rallison syndrome, cystic fibrosis-related diabetes, and maternally inherited diabetes and deafness.

Conclusions: Genetically confirmed monogenic diabetes accounted for $5.1 \%$ of patients evaluated at a single tertiary center over 20-year period. Based on the findings for our sample, the frequency of mutations in the major genes of MODY appears to be low among pediatric patients in Korea. It is critical to identify the genetic cause of DM to provide appropriate therapeutic options and genetic counseling.
\end{abstract}

Keywords: Maturity-onset diabetes of the young, Monogenic diabetes, Type 1 diabetes mellitus, Type 2 diabetes mellitus

\footnotetext{
* Correspondence: jhc@amc.seoul.kr

${ }^{1}$ Department of Pediatrics, Medical Genetics Center, Asan Medical Center,

University of Ulsan College of Medicine, 88, Olympic-Ro 43-Gil, Songpa-Gu,

Seoul 05505, Republic of Korea

Full list of author information is available at the end of the article
}

(c) The Author(s). 2021 Open Access This article is licensed under a Creative Commons Attribution 4.0 International License, which permits use, sharing, adaptation, distribution and reproduction in any medium or format, as long as you give appropriate credit to the original author(s) and the source, provide a link to the Creative Commons licence, and indicate if changes were made. The images or other third party material in this article are included in the article's Creative Commons licence, unless indicated otherwise in a credit line to the material. If material is not included in the article's Creative Commons licence and your intended use is not permitted by statutory regulation or exceeds the permitted use, you will need to obtain permission directly from the copyright holder. To view a copy of this licence, visit http://creativecommons.org/licenses/by/4.0/. The Creative Commons Public Domain Dedication waiver (http://creativecommons.org/publicdomain/zero/1.0/) applies to the data made available in this article, unless otherwise stated in a credit line to the data. 


\section{Background}

Among children and adolescents with diabetes mellitus (DM), type $1 \mathrm{DM}$ is the most common, especially in North America and Europe [1]. However, the annual incidence of type 1 DM varies according to the ethnic background, and worldwide incidence has increased in the past two decades [1-3]. In Korea, the annual incidence of type $1 \mathrm{DM}$ increased from 1.36/100,000 in 1995-2000 to $3.19 / 100,000$ in 2012-2014 [4]. In addition, increasing worldwide rates of child obesity have been associated with a variable increase in the prevalence of type 2 DM depending on the ethnic background and region of residence [2].

Most DM cases are classified as type 1 or type 2 DM (i.e., of multifactorial etiology). Type $1 \mathrm{DM}$ is primarily caused by the autoimmune destruction of pancreatic $\beta$ cells [5]. A substantial proportion of type $2 \mathrm{DM}$ is caused by environmental and multiple genetic defects with a smaller effect size. Compared with type 2 DM, monogenic diabetes, including maturity-onset diabetes of the young (MODY), is a rare form of DM caused by mutations in one of more than 20 genes that control either the secretion or action of insulin [6]. Monogenic diabetes is characterized by Mendelian inheritance pattern with a large effect size of causal variants and minimal environmental contributions [7]. The prevalence of monogenic diabetes is estimated to be $1.1-6.3 \%$ among children and adolescents with DM in Europe [8-13].

It is important to make an accurate etiologic diagnosis of DM since it can affect the therapeutic decisions, the prognosis of chronic complications, and genetic counseling [14]. However, the overlapping clinical features of various forms of DM make it difficult to perform differential etiologic diagnosis. Information on the distribution of the type of DM and the prevalence of monogenic diabetes has not been established in the Korean pediatric population. A few studies on MODY in Korea demonstrated that mutations in the major MODY genes, including some cases with GCK mutations, were rare [1518]. Therefore, this study was performed to investigate the etiologic distribution and clinical characteristics of pediatric diabetes including monogenic diabetes at a single tertiary center over a 20-year period in Korea.

\section{Methods/design}

\section{Subjects}

Three hundred and sixty-two patients diagnosed with DM before the age of 18 years who presented at the Department of Pediatrics, Asan Medical Center Children's Hospital, or were referred from another hospital between January 2000 and December 2019, were included in the study. However, 47 patients with type $1 \mathrm{DM}$ and 10 patients with type $2 \mathrm{DM}$ who were referred from another hospital were excluded from the study owing to insufficient clinical and laboratory data, and 29 patients with secondary DM due to corticosteroid or immunosuppressant use were also excluded because these patients showed different clinical course of transient hyperglycemia. Ultimately, 276 consecutively presenting pediatric patients were included.

Clinical and endocrine characteristics such as the patients' age at diagnosis, gender, C-peptide level, presence of $\beta$-cell autoantibodies (glutamic acid decarboxylase antibody and insulin autoantibody), and presence of diabetic ketoacidosis (DKA) at diagnosis, were retrospectively collected using a medical chart review. Laboratory tests were performed at the time of diagnosis at a single academic center.

Type 1 DM was diagnosed in the presence of low Cpeptide levels, $\beta$-cell autoantibody positivity, and the absence of acanthosis nigricans or any extra-pancreatic features suggesting monogenic diabetes. The diagnosis of type 2 DM was based on clinical findings, such as a family history of type 2 DM, obesity, and signs of insulin resistance (acanthosis nigricans). The patients were categorized as having monogenic diabetes when they showed clinical features, such as a family history of DM, the absence of $\beta$-cell autoantibodies, normal or high $\mathrm{C}$-peptide levels, a low-dose insulin requirement, and signs of extra-pancreatic features [14].

Four patients with monogenic diabetes previously reported by our group [19-22] were included to delineate the clinical and molecular spectrum of monogenic diabetes in the cohort included in the current research. This study was approved by the Institutional Review Board of Asan Medical Center, Seoul, Korea (IRB No. 2020-0667). Blood samples for DNA analysis were collected after obtaining written informed consent from the patients or their parents. Informed consent was obtained from both the parents and patient for participation by pediatric patients aged 7-17 years.

\section{Molecular analysis for patients with monogenic diabetes} Genomic DNA was extracted from peripheral blood leukocytes using the Gentra Puregene Blood kit (Qiagen, Hilden, Germany). Molecular analysis was performed by Sanger sequencing for patients with a clinical diagnosis of monogenic diabetes according to the patients' phenotype. Sanger sequencing of the major genes (HNF1A, $H N F 4 A$, and GCK genes) involved in MODY was performed when MODY was clinically suspected: 1) a family history of diabetes in one parent and in a first-degree relatives of the affected parent; 2) negative autoantibodies; 3 ) lack of the characteristics of type 2 DM (obesity and acanthosis nigricans); and 4) good metabolic control with diet, sulfonylurea therapy, or low-dose insulin [14]. In cases with defects of the urogenital tract, 
$H N F 1 B$ was analyzed. DNA sequencing of INSR was performed for a patient with severe insulin resistance.

For patients with MODY, whole exome sequencing was performed when there were no rare sequence variants in the major MODY genes. SureSelect Human All Exon V5 (Agilent Technologies, Santa Clara, CA, USA) was used for library preparation. Sequencing was performed using the NextSeq500 platform (Illumina Inc., San Diego, CA, USA), generating $2 \times 150$ bp paired-end reads. The sequence reads were aligned to the human reference genome (hg19) using the Burrow-Wheeler Alignment program (BWA version 0.7.12). SAMtools 0.1.19 and Genome Analysis Toolkits (GATK version 3.5) were used for single nucleotide polymorphism variant calling from aligned sequence reads. GATK version 3.5, FreeBayes 0.9.2.1, and Scalpel 0.5.3 were used for insertion-deletion variant calling. After removing duplicates with Picard (version 1.96), annotation was performed using Variant Effect Predictor [23] and dbNSFP [24]. The sequence variants of known genes previously associated with MODY were scanned [25]. All sequence variants were classified as pathogenic, likely pathogenic, variant of uncertain significance (VUS), likely benign, or benign, in accordance with the standards and guidelines of the American College of Medical Genetics and Genomics and the Association for Molecular Pathology [26].

\section{Results}

\section{Clinical and molecular characteristics of patients with} type 1 and type 2 diabetes mellitus

Of the 276 patients, 206 (74.6\%), 49 (17.8\%), and 21 (7.6\%) patients were diagnosed with type $1 \mathrm{DM}$, type 2 $\mathrm{DM}$, and clinically suspected monogenic diabetes, respectively (Fig. 1). The clinical characteristics at diagnosis of type $1 \mathrm{DM}$, type $2 \mathrm{DM}$, and monogenic diabetes are shown in Table 1 . Trend of frequency of new diabetes cases is detailed in Fig. 2; in particular, the frequency of type $2 \mathrm{DM}$ increased during the study period.

Of the 206 patients with type $1 \mathrm{DM}$, the mean age at diagnosis was $9.9 \pm 3.8$ years (median, 10.4 years; range, $0.8-17.6$ years). The frequency of DKA at diagnosis in type $1 \mathrm{DM}$ participants was $19.4 \%(n=40)$. The $\beta$-cell autoantibodies of 190 patients were analyzed. Among them, 137 patients $(72.1 \%)$ had at least one $\beta$-cell autoantibody. The mean serum $\mathrm{C}$-peptide level at diagnosis was $0.9 \pm 1.0 \mathrm{ng} / \mathrm{mL}$ (reference range, $0.48-3.3 \mathrm{ng} / \mathrm{mL}$ ).

Among 49 patients with type $2 \mathrm{DM}(17.8 \%)$, the mean age at diagnosis was $13.7 \pm 2.1$ years (median, 13.5 years; range, $8.0-16.8$ years). The mean fasting serum Cpeptide level (available for 44 patients) was $4.7 \pm 2.7 \mathrm{ng} /$ $\mathrm{mL}$. DKA and hyperosmolar hyperglycemic state were observed at diagnosis in 1 patient (2.0\%) with type 2
DM. Antibody positivity was $14.3 \%$ (7 patients) in type 2 DM participants.

\section{Clinical and molecular characteristics of patients with genetically confirmed monogenic diabetes}

Of the 276 patients, 21 patients $(7.6 \%)$ were suspected to have monogenic diabetes; 8 of these patients had clinical MODY, and the remaining 13 patients had other types of monogenic diabetes. Among them, genetic etiologies were identified in 14 patients $(5.1 \%)$ from 13 families (Table 2, Supplementary Table 1).

\section{Maturity-onset diabetes of the young}

Eight patients were suspected to have clinical MODY (Table 3). Their mean age at diagnosis was $13.5 \pm 2.8$ years (range, 9.4-18.5 years). The patients were nonobese with a body mass index (BMI) of $19.3 \pm 1.3 \mathrm{~kg} / \mathrm{m}^{2}$ and normal serum $\mathrm{C}$-peptide levels at diagnosis $(2.2 \pm$ $1.9 \mathrm{ng} / \mathrm{mL}$ ). A 14.6-year-old girl was diagnosed with MODY 5 with heterozygous mutations in $H N F 1 B$ (c.443C $>\mathrm{T}$ [p.S148L] in exon 2), which was previously reported to be pathogenic [27]. She underwent renal transplantation at the age of 16.1 years owing to chronic renal failure. Rare sequence variants in the genes associated with monogenic diabetes were not identified using whole exome sequencing in the remaining 7 patients.

\section{Neonatal diabetes mellitus}

Two patients were diagnosed with neonatal DM, one with a transient form caused by paternal uniparental disomy of $6 \mathrm{q} 24$ and the other with a permanent form with a heterozygous mutation (c.602G > A [p.R201H]) in $K C N J 11$, leading to developmental delay, epilepsy, and neonatal diabetes (DEND) syndrome [20]. The patient with DEND syndrome was initially misdiagnosed as having type $1 \mathrm{DM}$; however, insulin therapy was successfully switched to oral sulfonylurea therapy.

\section{Wolfram syndrome}

Two male siblings were initially misdiagnosed with type $1 \mathrm{DM}$ at the age of 4.9 and 6.1 years, respectively, until urinary incontinence and bilateral optic nerve atrophy occurred. They were compound heterozygous for a known pathogenic c.2171C > T (p.P724L) mutation [28] and a novel c.1725_1742del (p.G587_G592del) mutation in WFS1.

\section{Donohue syndrome}

A male newborn with acanthosis nigricans, hirsutism, high insulin levels, and intrauterine growth retardation was compound heterozygous for c.3196C > T (p.R1066*) and c.3614C $>\mathrm{T}$ (p.Q1232*) in the tyrosine kinase domain of the $\beta$-subunit in INSR [21]. 


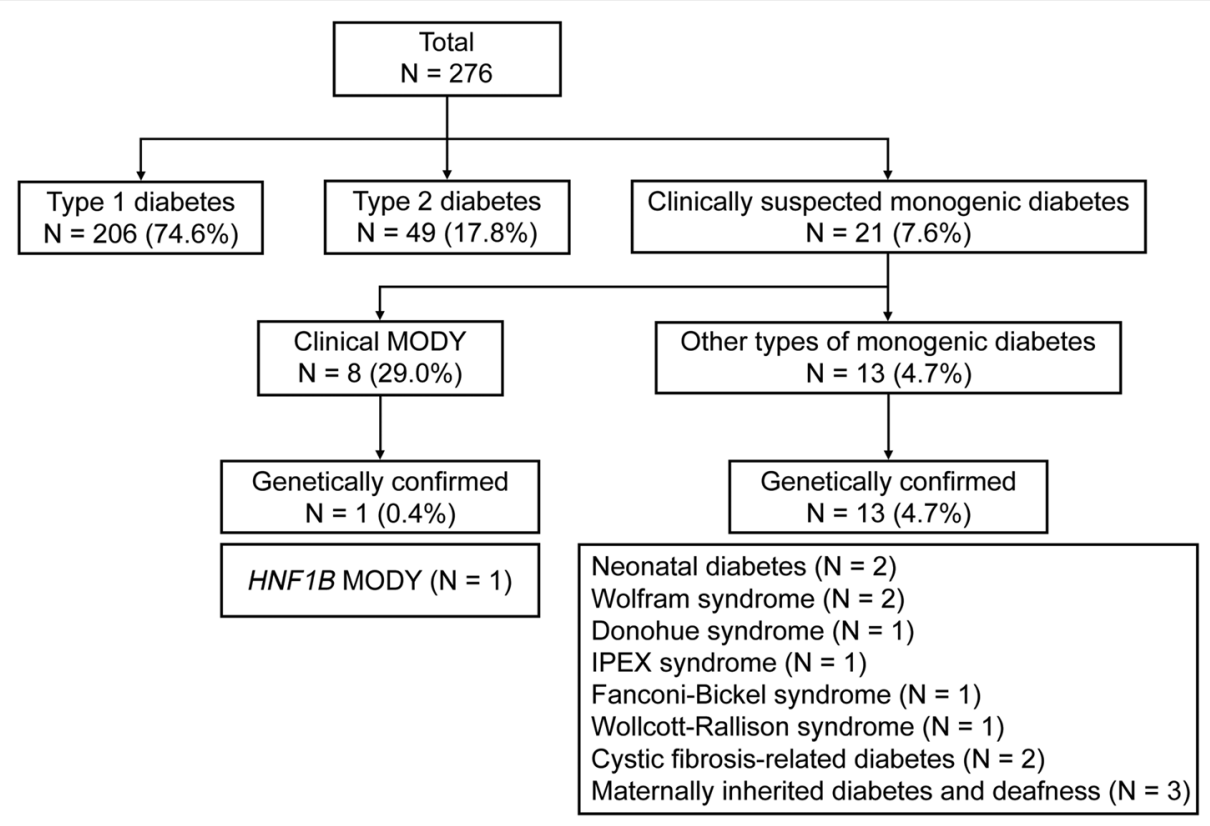

Fig. 1 A flow chart illustrating the etiologic spectrum of pediatric diabetes mellitus (DM). MODY, maturity-onset diabetes of the young

Immune dysregulation, polyendocrinopathy, enteropathy, Xlinked (IPEX) syndrome

The patient was initially misdiagnosed as having type $1 \mathrm{DM}$ at the age of 11 months. However, he showed unusual clinical features including pure red cell aplasia and membranous glomerulopathy at the age of 39 months, and posterior reversible encephalopathy syndrome after a vaccination against influenza $\mathrm{A}$ (H1N1) virus at the age of 11 years. DNA analysis of the FOXP3 gene identified a splice site mutation of c. $201+1 G>A$, which was inherited from his mother [19].

\section{Fanconi-Bickel syndrome}

A 3-day-old female presented with hyperglycemia, glycosuria, and galactosemia. She failed to grow during the follow-up period, and her liver function deteriorated with micronodular cirrhosis and marked fatty changes on liver biopsy. Homozygous mutation of c.13A $>\mathrm{T}$ (p.K5*) in exon 1 was identified by Sanger sequencing of SLC2A2 [22].

\section{Wolcott-Rallison syndrome}

A 3-month-old Arab female infant presented with neonatal DM, epiphyseal dysplasia, and liver failure; she was diagnosed with Wolcott-Rallison syndrome caused by the pathogenic homozygous mutation of c.1293G > A (p.W431*) in EIF2AK3, which was previously reported to be pathogenic [29].

\section{Cystic fibrosis-related diabetes}

Cystic fibrosis-related diabetes was detected in two patients with CFTR mutations. They showed pancreatitisrelated hyperglycemia at the age of 7.7 and 14.2 years, respectively, without $\beta$-cell autoantibodies.

\section{Maternally inherited diabetes and deafness}

Three patients with m.3243A > G mutation in MTTL1 were diagnosed with maternally inherited diabetes and deafness with a hemoglobin A1c (HbA1c) level of $8.2 \pm$ $2.8 \%$ without $\beta$-cell autoantibodies. All patients have been treated with insulin injections.

\section{Discussion}

This study described the clinical characteristics of different types of DM based on the experiences of a single tertiary center over the last 20 years. Type $1 \mathrm{DM}$ accounted for most cases $(74.6 \%)$ of DM in the cohort, followed by type 2 DM (17.8\%). Genetic etiologies were confirmed in 14 patients $(5.1 \%)$ from 13 families. Diverse genetic etiologies are associated with pediatric monogenic diabetes, and extra-pancreatic features were found to be an important clue to the diagnosis of monogenic diabetes.

The frequencies of type 1 DM, type 2 DM, and MODY were $85.6,10.8$, and $1.2 \%$, respectively, in the SEARCH study (USA); on the other hand, these ratios were 95.5, 1.3 , and $1.5 \%$, respectively, in the SWEET study (Europe) [30-32]. The diagnosis of type 2 DM (17.8\%) and genetically confirmed monogenic diabetes (5.1\%) was more common in the present study compared with the 
Table 1 Clinical features of patients with diabetes mellitus (DM) at diagnosis

\begin{tabular}{llllllll}
\hline & Type 1 DM & Type 2 DM & MODY & Neonatal DM & CFRD & Genetic syndromes & MIDD \\
\hline Patients, n (\%) & $206(74.6)$ & $49(17.8)$ & $8(2.9)$ & $2(0.7)$ & $2(0.7)$ & $6(2.2)$ & $3(1.1)$ \\
Age at diagnosis, years & $9.9 \pm 3.8$ & $13.7 \pm 2.1$ & $13.5 \pm 2.8$ & 0.1 & 10.6 & $2.1 \pm 2.7$ & $4.1 \pm 0.9$ \\
BMI Z-score & $-0.83 \pm 1.22$ & $2.59 \pm 1.47$ & $-0.33 \pm 1.00$ & NA & $0.45 \pm 4.01$ & NA & $-3.29 \pm 2.05$ \\
HbA1c, \% & $12.1 \pm 2.5$ & $10.0 \pm 2.0$ & $9.7 \pm 3.0$ & NA & 6.9 & $9.4 \pm 2.9$ & $8.2 \pm 2.8$ \\
C-peptide, ng/mL & $0.9 \pm 1.0$ & $4.7 \pm 2.7$ & $2.2 \pm 1.9$ & 0.45 & 3.1 & $22.9 \pm 38.8$ & $6.3 \pm 4.9$ \\
Antibody positivity, n (\%) & $137 / 190(72.1)$ & $7 / 49(14.3)$ & 0 & 0 & 0 & 0 & 0 \\
DKA at diagnosis, n (\%) & $40(19.4)$ & $1(2.0)$ & 0 & 0 & 0 & 0 & 0 \\
\hline
\end{tabular}

$B M I$ body mass index, CFRD cystic fibrosis-related diabetes, DKA diabetic ketoacidosis, HbA1c hemoglobin A1c, MIDD maternally inherited diabetes and deafness, NA not available

previous studies. The variation in the frequencies could be explained by the availability of genetic testing and the prevalence of obesity in the region. Antibody positivity has been reported in up to $15 \%$ of patients with type 2 $\mathrm{DM}$, and these autoantibody-positive patients are usually younger, less overweight or obese, and have higher HbA1c levels [33]. However, there were no significant differences in the current study.

Monogenic diabetes comprises various phenotypes including neonatal DM, MODY, and rare syndromic diabetes with extra-pancreatic features including neurological, renal, intestinal, or skeletal abnormalities [6]. Therefore, monogenic diabetes might be initially misdiagnosed as type 1 or type $2 \mathrm{DM}$ prior to the manifestation of extra-pancreatic features, as in the case of the patients with Wolfram syndrome, DEND syndrome, and IPEX syndrome in the present study.

Establishing the etiology of DM is important for therapeutic strategies, the prognosis of chronic complications [14], and appropriate genetic counseling for monogenic diabetes [6]. For example, the molecular diagnosis of monogenic diabetes can lead to changes in treatment, often with improved glycemic control, as some patients with monogenic diabetes carrying mutations in specific genes (e.g., $H N F 1 A, H N F 4 A$, $K C N J 11$, and $A B C C 8$ ) can be treated with oral sulfonylureas instead of insulin [34].

MODY is defined as an autosomal dominantly inherited familial form of non-autoimmune diabetes due to a primary defect in pancreatic $\beta$-cell function with an age of onset before 25 years of age [35]. Mutations in 14 different genes are known to be associated with MODY [https://www.omim.org/entry/606391, accessed on January 2021]. Among them, mutations in HNF4A, HNF1A, and GCK are the most common causes of MODY [36]. The prevalence of MODY has been estimated to be 1$2 \%$ of cases of DM [37]. In an Italian study, MODY was the second most prevalent cause (5.5\%) of DM after type $1 \mathrm{DM}$; however, mutations in MODY-related genes were documented in approximately $1.9 \%$ of patients [9]. In India, sequence variants in MODY genes were identified in $15-19 \%$ of patients with clinically diagnosed MODY in India $[38,39]$. Among them, $H N F 1 A$ or $A B C C 8$ mutations were the most common [39]. The frequency of mutations in the major MODY genes (HNF4A, GCK, and $H N F 1 A$ ) has been shown to be extremely low among Korean patients with MODY [17, 25]. However, with the advent of next-generation sequencing, rate at

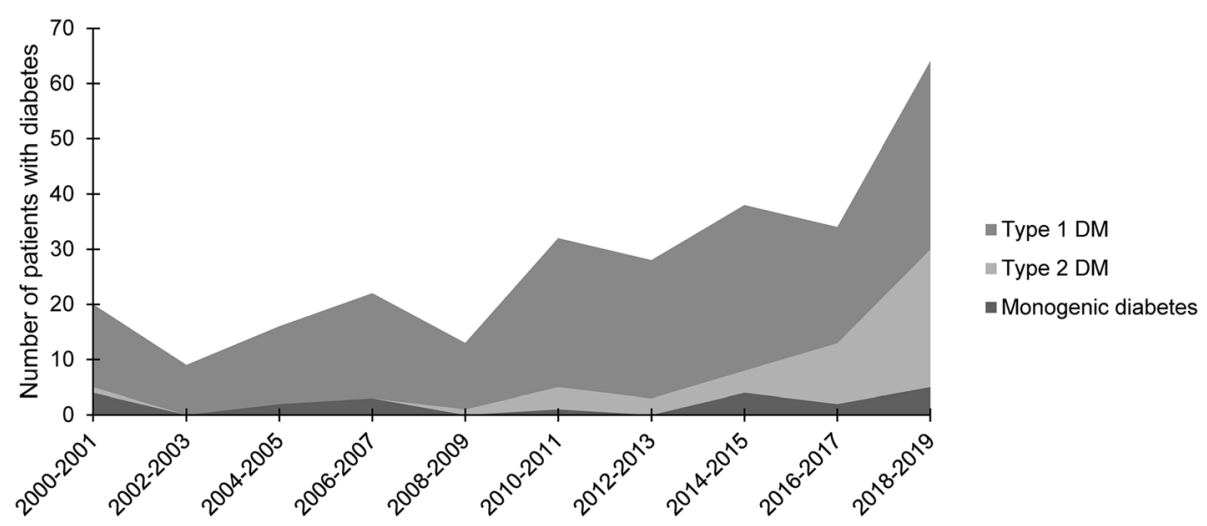

Fig. 2 The annual frequency of diabetes mellitus (DM) by type in children and adolescents at a single academic center 
Table 2 Mutations in genes associated with monogenic diabetes

\begin{tabular}{|c|c|c|c|c|c|c|}
\hline Gene & Nucleotide change & Amino acid change & Exon/Intron & Segregation data & ACMG/AMP guidelines & Phenotype \\
\hline$\overline{H N F 1 B}$ & C. $443 C>T$ & p.S148L & 1 & NA & Pathogenic & MODY 5 \\
\hline KCNJ11 & c. $602 \mathrm{G}>\mathrm{A}$ & p.R201H & 1 & NA & Pathogenic & DEND syndrome \\
\hline WFS1 & c. $2171 C>T$ & p.P724L & 8 & Sibling & Pathogenic & Wolfram syndrome \\
\hline WFS1 & c.1725_1742del & p.G587_G592del & 8 & Sibling & Likely pathogenic & Wolfram syndrome \\
\hline INSR & c.3196C > T & p.R1066* & 17 & Paternal & Pathogenic & Donohue syndrome \\
\hline INSR & c. $3614 C>T$ & p.Q1232* & 21 & Maternal & Pathogenic & Donohue syndrome \\
\hline FOXP3 & c. $201+1 \mathrm{G}>\mathrm{A}$ & Splice site & 1 & Maternal & Pathogenic & IPEX syndrome \\
\hline$S L C 2 A 2$ & c. $13 \mathrm{~A}>\mathrm{T}$ & p.K5* & 1 & NA & Pathogenic & Fanconi-Bickel syndrome \\
\hline EIF2AK3 & c. $1293 G>A$ & p.W431* & 6 & NA & Likely pathogenic & Wolcott-Rallison syndrome \\
\hline CFTR & c. $4056 \mathrm{G}>\mathrm{C}$ & p.Q1352H & 25 & NA & Uncertain significance & CFRD \\
\hline CFTR & c. $1322 \mathrm{~T}>\mathrm{C}$ & p.L441P & 10 & NA & Uncertain significance & CFRD \\
\hline MTTL1 & m.3243A > G & Mitochondrial gene & Mitochondrial gene & NA & Pathogenic & MIDD \\
\hline
\end{tabular}

Bold, novel mutation; ACMG/AMP Interpretation according to the guidelines of the American College of Medical Genetics and Genomics (ACMG) and the Association for Molecular Pathology (AMP) [24], NA not available

which MODY is diagnosed using genetic screening has increased. In 28 patients with early-onset diabetes in Korea, four pathogenic or likely pathogenic variants were identified in three patients usingy whole exome sequencing [40]. In targeted panel sequencing, molecular genetic diagnosis was possible in $21.1 \%$ of 109 patients who were clinically suspected to have monogenic diabetes [41].

A diagnosis of MODY is dependent on the active referral of patients who are likely to have MODY, which suggests that some patients with MODY remain underdiagnosed [42]. Childhood type $2 \mathrm{DM}$ can be confused with MODY owing to a family history and presenting features, as well as obesity or overweight as a possible confounding factor [11]. Clinically, MODY should be considered in patients with atypical features for type 2 $\mathrm{DM}$, including diabetes onset before the age of 45 years, a normal or low BMI, lack of acanthosis nigricans, and normal serum triglyceride levels and/or normal or elevated high-density lipoprotein cholesterol concentrations [43]. In addition, high-sensitivity C-reactive protein levels are low in HNF1A-MODY and can be used to distinguish between HNF1A-MODY and type 2 DM [44]. In addition, MODY can be misclassified as type $1 \mathrm{DM}$, especially in cases involving HNF1A mutations [9].

However, MODY can be differentiated from type 1 DM by atypical features of type $1 \mathrm{DM}$. including the absence of pancreatic autoantibodies, low insulin requirements, evidence of endogenous insulin production with detectable serum C-peptide $(>0.6 \mathrm{ng} / \mathrm{mL})$, and the $\mathrm{ab}$ sence of DKA [43]. An additional, non-invasive 2-h postprandial urinary $\mathrm{C}$-peptide to creatinine ratio (UCPCR) test can be used to distinguish between long-standing type $1 \mathrm{DM}$ and HNF1A-MODY and HNF4A-MODY. A

Table 3 Clinical and endocrinological characteristics at diagnosis in 8 patients with clinical MODY

\begin{tabular}{|c|c|c|c|c|c|c|c|c|c|c|}
\hline \multirow[t]{2}{*}{$\begin{array}{l}\text { Subject } \\
\text { No. }\end{array}$} & \multirow[t]{2}{*}{ Molecular defect } & \multirow[t]{2}{*}{ Sex } & \multirow{2}{*}{$\begin{array}{l}\text { Age at } \\
\text { diagnosis } \\
\text { (year) }\end{array}$} & \multirow{2}{*}{$\begin{array}{l}\text { Number of } \\
\text { generations } \\
\text { with DM }\end{array}$} & \multirow[t]{2}{*}{ BMI } & \multirow[t]{2}{*}{$\begin{array}{l}\mathrm{HbA1c}, \\
\%\end{array}$} & \multirow{2}{*}{$\begin{array}{l}\text { Serum } \\
\text { C- } \\
\text { peptide, } \\
\mathrm{ng} / \mathrm{mL} \\
(0.48- \\
3.3)\end{array}$} & \multicolumn{2}{|c|}{$\begin{array}{l}\text { Presence of } \\
\beta \text {-cell antibodies }(A b)\end{array}$} & \multirow[t]{2}{*}{ Microangiopathy } \\
\hline & & & & & & & & $\begin{array}{l}\text { GAD Ab, U/mL } \\
(0-1)\end{array}$ & $\begin{array}{l}\text { Insulin Ab, \% } \\
(0-7)\end{array}$ & \\
\hline 1 & $\begin{array}{l}\text { HNF1B c.443C > T } \\
\text { (p.S148L) }\end{array}$ & $\mathrm{F}$ & 14.6 & 0 & 19 & 6 & 0.58 & NA & NA & Nephropathy \\
\hline 2 & ND & $\mathrm{F}$ & 11.8 & 3 & 21.8 & 8.7 & 4.4 & 0.1 & 4.4 & None \\
\hline 3 & ND & M & 13 & 3 & 17.7 & 14.4 & 0.37 & $<0.1$ & NA & None \\
\hline 4 & ND & M & 18.5 & 0 & 18.4 & 7.7 & 1.4 & 1.1 & 6.6 & None \\
\hline 5 & ND & $\mathrm{F}$ & 12.3 & 2 & 19.2 & 12.9 & 1.1 & 0.94 & 6.3 & None \\
\hline 6 & ND & M & 12.3 & 3 & 20.4 & 9.5 & 2.4 & 0.41 & 6 & None \\
\hline 7 & ND & M & 15.7 & 2 & 18 & 11.5 & 1.8 & 0.28 & 5.7 & None \\
\hline 8 & ND & $\mathrm{F}$ & 9.4 & 3 & 19.6 & 6.7 & 5.7 & 1.1 & 5.1 & None \\
\hline
\end{tabular}


UCPCR of $\geq 0.2 \mathrm{nmol} / \mathrm{mmol}$ is $97 \%$ sensitive and $96 \%$ specific for differentiating HNF1A- and HNF4A-MODY from type 1 DM [45].

A correct diagnosis of MODY is important for the treatment and identification of affected or at-risk family members. Despite the low frequency of MODY among pediatric DM patients, non-obese individuals with a family history of DM and those who lack the clinical characteristics of type $1 \mathrm{DM}$ and type $2 \mathrm{DM}$ should be evaluated for MODY using a high index of suspicion.

This study had several limitations. This study is not a national multicenter study and investigated etiologic distribution of DM in pediatric patients under 18 years of age at diagnosis who were diagnosed at a single tertiary center. Thus, the frequency of specific types of DM may not reflect the actual frequency.

\section{Conclusions}

This study showed that genetically confirmed monogenic diabetes accounted for $5.1 \%$ of patients evaluated at a single tertiary center over 20 years. Based on our sample, the frequency of mutations in the major MODY genes appears low among pediatric patients in Korea. Healthcare providers should have a high index of suspicion that diabetic patients with a family history of DM or extra-pancreatic features without $\beta$-cell autoantibodies might have monogenic diabetes.

\section{Abbreviations}

DEND: developmental delay, epilepsy, and neonatal diabetes; DKA: diabetic ketoacidosis; DM: diabetes mellitus; IPEX: immune dysregulation, polyendocrinopathy, enteropathy, X-linked; MIDD: maternally inherited diabetes and deafness; MODY: maturity-onset diabetes of the young; VUS: variant of uncertain significance

\section{Supplementary Information}

The online version contains supplementary material available at https://doi. org/10.1186/s12887-021-02575-6.

\section{Additional file 1.}

\section{Acknowledgements}

Not applicable.

\section{Authors' contributions}

JHK and JHC designed the study and wrote the manuscript; YL, YC, GHK, and HWY collected the data and were involved in the data analysis. All the authors made final corrections and approved the manuscript.

\section{Funding}

Whole exome sequencing in this study was supported by a grant (2018-481) from Asan Medical Center Children's Hospital, Seoul, Korea.

\section{Availability of data and materials}

The datasets used and/or analyzed during the current study are available from the corresponding author on reasonable request.

\section{Declarations}

\section{Ethics approval and consent to participate}

This study was approved by the Institutional Review Board of Asan Medical Center, Seoul, Korea (IRB No. 2020-0667). Sanger sequencing and whole exome sequencing were performed after obtaining written informed consent from patients or their parents. In pediatric patients aged 7-17 years, the informed consent was obtained from both the parent and the patients. The need to obtain informed consent was waived by the IRB when the clinical data were obtained retrospectively without molecular analysis.

Consent for publication

Not applicable.

\section{Competing interests}

The authors declare that they have no competing interests.

\section{Author details}

${ }^{1}$ Department of Pediatrics, Medical Genetics Center, Asan Medical Center, University of Ulsan College of Medicine, 88, Olympic-Ro 43-Gil, Songpa-Gu, Seoul 05505, Republic of Korea. ${ }^{2}$ Medical Genetics Center, Asan Medical Center, University of Ulsan College of Medicine, Seoul, Republic of Korea.

Received: 12 September 2020 Accepted: 24 February 2021

Published online: 04 March 2021

\section{References}

1. Maahs DM, West NA, Lawrence JM, Mayer-Davis EJ. Epidemiology of type 1 diabetes. Endocrinol Metab Clin N Am. 2010;39(3):481-97.

2. Patterson C, Guariguata L, Dahlquist G, Soltesz G, Ogle G, Silink M. Diabetes in the young - a global view and worldwide estimates of numbers of children with type 1 diabetes. Diabetes Res Clin Pract. 2014;103(2):161-75.

3. Patterson CC, Dahlquist GG, Gyurus E, Green A, Soltesz G, Group ES. Incidence trends for childhood type 1 diabetes in Europe during 1989-2003 and predicted new cases 2005-20: a multicentre prospective registration study. Lancet. 2009;373(9680):2027-33.

4. Kim JH, Lee CG, Lee YA, Yang SW, Shin CH. Increasing incidence of type 1 diabetes among Korean children and adolescents: analysis of data from a nationwide registry in Korea. Pediatr Diabetes. 2016;17(7):519-24.

5. Mayer-Davis EJ, Kahkoska AR, Jefferies C, Dabelea D, Balde N, Gong CX, Aschner P, Craig ME. ISPAD Clinical Practice Consensus Guidelines 2018: Definition, epidemiology, and classification of diabetes in children and adolescents. Pediatr Diabetes. 2018:19(Suppl 27):7-19.

6. Vaxillaire M, Bonnefond A, Froguel P. The lessons of early-onset monogenic diabetes for the understanding of diabetes pathogenesis. Best Pract Res Clin Endocrinol Metab. 2012;26(2):171-87.

7. Flannick J, Johansson S, Njolstad PR. Common and rare forms of diabetes mellitus: towards a continuum of diabetes subtypes. Nat Rev Endocrinol. 2016;12(7):394-406.

8. Haliloglu B, Abali S, Bugrul F, Celik E, Bas S, Atay Z, Guran T, Turan S, Bereket A. The distribution of different types of diabetes in childhood: a single center experience. J Clin Res Pediatr Endocrinol. 2018;10(2):125-30.

9. Delvecchio M, Mozzillo E, Salzano G, lafusco D, Frontino G, Patera PI, Rabbone I, Cherubini V, Grasso V, Tinto N, et al. Monogenic diabetes accounts for $6.3 \%$ of cases referred to 15 Italian pediatric diabetes centers during 2007 to 2012. J Clin Endocrinol Metab. 2017;102(6):1826-34.

10. Malachowska B, Borowiec M, Antosik K, Michalak A, Baranowska-Jazwiecka A, Deja G, Jarosz-Chobot P, Brandt A, Mysliwiec M, Stelmach M, et al. Monogenic diabetes prevalence among polish children-summary of 11 years-long nationwide genetic screening program. Pediatr Diabetes. 2018; 19(1):53-8.

11. Mozzillo E, Salzano G, Barbetti F, Maffeis C, Lombardo F, Franzese A, Delvecchio M, Marigliano M. Survey on etiological diagnosis of diabetes in 1244 Italian diabetic children and adolescents: impact of access to genetic testing. Diabetes Res Clin Pract. 2015;107(3):e15-8.

12. Fendler W, Borowiec M, Baranowska-Jazwiecka A, Szadkowska A, SkalaZamorowska E, Deja G, Jarosz-Chobot P, Techmanska I, BautembachMinkowska J, Mysliwiec M, et al. Prevalence of monogenic diabetes amongst polish children after a nationwide genetic screening campaign. Diabetologia. 2012;55(10):2631-5. 
13. Irgens $H U$, Molnes J, Johansson BB, Ringdal M, Skrivarhaug $T$, Undlien DE, Sovik O, Joner G, Molven A, Njolstad PR. Prevalence of monogenic diabetes in the population-based Norwegian childhood diabetes registry. Diabetologia. 2013;56(7):1512-9.

14. Hattersley AT, SAW G, Polak M, Rubio-Cabezas O, Njolstad PR, Mlynarski W, Castano L, Carlsson A, Raile K, Chi DV, et al. ISPAD Clinical Practice Consensus Guidelines 2018: The diagnosis and management of monogenic diabetes in children and adolescents. Pediatr Diabetes. 2018;19(Suppl 27): 47-63.

15. Cho YK, Cho EH, Choi HS, Kim SW. Novel deletion mutation in the glucokinase gene from a korean man with GCK-MODY phenotype and situs inversus. Diabetes Res Clin Pract. 2018;143:263-6.

16. Cho EH, Min JW, Choi SS, Choi HS, Kim SW. Identification of maturity-onset diabetes of the young caused by Glucokinase mutations detected using whole-exome sequencing. Endocrinol Metab (Seoul). 2017;32(2):296-301.

17. Hwang JS, Shin CH, Yang SW, Jung SY, Huh N. Genetic and clinical characteristics of Korean maturity-onset diabetes of the young (MODY) patients. Diabetes Res Clin Pract. 2006;74(1):75-81.

18. Lee HJ, Ahn CW, Kim SJ, Song YD, Lim SK, Kim KR, Lee HC, Huh KB. Mutation in hepatocyte nuclear factor-1alpha is not a common cause of MODY and early-onset type 2 diabetes in Korea. Acta Diabetol. 2001;38(3): $123-7$.

19. Bae KW, Kim BE, Choi JH, Lee JH, Park YS, Kim GH, Yoo HW, Seo JJ. A nove mutation and unusual clinical features in a patient with immune dysregulation, polyendocrinopathy, enteropathy, X-linked (IPEX) syndrome. Eur J Pediatr. 2011;170(12):1611-5.

20. Cho JH, Kang E, Lee BH, Kim GH, Choi JH, Yoo HW. DEND syndrome with heterozygous KCNJ11 mutation successfully treated with sulfonylurea. J Korean Med Sci. 2017;32(6):1042-5.

21. Choi JH, Kang M, Kim JH, Cho J, Kim GH, Yoo HW. Identification and functional characterization of two novel nonsense mutations in the betasubunit of INSR that cause severe insulin resistance syndrome. Horm Res Paediatr. 2015;84(2):73-8

22. Yoo HW, Shin YL, Seo EJ, Kim GH. Identification of a novel mutation in the GLUT2 gene in a patient with Fanconi-Bickel syndrome presenting with neonatal diabetes mellitus and galactosaemia. Eur J Pediatr. 2002;161(6): 351-3.

23. McLaren W, Gil L, Hunt SE, Riat HS, Ritchie GR, Thormann A, Flicek P, Cunningham F. The Ensembl variant effect predictor. Genome Biol. 2016; 17(1):122.

24. Liu X, Wu C, Li C, Boerwinkle E. dbNSFP v3.0: a one-stop database of functional predictions and annotations for human nonsynonymous and splice-site SNVs. Hum Mutat. 2016;37(3):235-41.

25. Shim YJ, Kim JE, Hwang SK, Choi BS, Choi BH, Cho EM, Jang KM, Ko CW Identification of candidate gene variants in Korean MODY families by whole-exome sequencing. Horm Res Paediatr. 2015;83(4):242-51.

26. Richards S, Aziz N, Bale S, Bick D, Das S, Gastier-Foster J, Grody WW, Hegde $M$, Lyon E, Spector E, et al. Standards and guidelines for the interpretation of sequence variants: a joint consensus recommendation of the American College of Medical Genetics and Genomics and the Association for Molecular Pathology. Genet Med. 2015;17(5):405-24.

27. Edghill EL, Bingham C, Ellard S, Hattersley AT. Mutations in hepatocyte nuclear factor-1 beta and their related phenotypes. J Med Genet. 2006;43(1): 84-90.

28. Inoue $H$, Tanizawa $Y$, Wasson J, Behn P, Kalidas K, Bernal-Mizrachi E, Mueckler M, Marshall $H$, Donis-Keller $H$, Crock $P$, et al. A gene encoding a transmembrane protein is mutated in patients with diabetes mellitus and optic atrophy (Wolfram syndrome). Nat Genet. 1998;20(2):143-8.

29. Rubio-Cabezas O, Patch AM, Minton JA, Flanagan SE, Edghill EL, Hussain K, Balafrej A, Deeb A, Buchanan CR, Jefferson IG, et al. Wolcott-Rallison syndrome is the most common genetic cause of permanent neonatal diabetes in consanguineous families. J Clin Endocrinol Metab. 2009;94(11): 4162-70.

30. Pettitt DJ, Talton J, Dabelea D, Divers J, Imperatore G, Lawrence JM, Liese AD, Linder B, Mayer-Davis EJ, Pihoker C, et al. Prevalence of diabetes in U.S. youth in 2009: The SEARCH for diabetes in youth study. Diabetes Care. 2014;37(2):402-8.

31. Pacaud D, Schwandt A, de Beaufort C, Casteels K, Beltrand J, Birkebaek NH, Campagnoli M, Bratina N, Limbert C, Mp O'Riordan S, et al. A description of clinician reported diagnosis of type 2 diabetes and other non-type 1 diabetes included in a large international multicentered pediatric diabetes registry (SWEET). Pediatr Diabetes. 2016;17(Suppl 23):24-31.

32. Pihoker C, Gilliam LK, Ellard S, Dabelea D, Davis C, Dolan LM, Greenbaum CJ, Imperatore G, Lawrence JM, Marcovina SM, et al. Prevalence, characteristics and clinical diagnosis of maturity onset diabetes of the young due to mutations in HNF1A, HNF4A, and glucokinase: results from the SEARCH for diabetes in youth. J Clin Endocrinol Metab. 2013;98(10):4055-62.

33. Zeitler P. Approach to the obese adolescent with new-onset diabetes. J Clin Endocrinol Metab. 2010;95(12):5163-70.

34. Pearson ER, Flechtner I, Njolstad PR, Malecki MT, Flanagan SE, Larkin B, Ashcroft FM, Klimes I, Codner E, lotova V, et al. Switching from insulin to oral sulfonylureas in patients with diabetes due to Kir6.2 mutations. N Engl J Med. 2006:355(5):467-77.

35. Molven A, Njolstad PR. Role of molecular genetics in transforming diagnosis of diabetes mellitus. Expert Rev Mol Diagn. 2011;11(3):313-20.

36. Ellard S, Bellanne-Chantelot C, Hattersley AT. European molecular genetics quality network mg: best practice guidelines for the molecular genetic diagnosis of maturity-onset diabetes of the young. Diabetologia. 2008;51(4): 546-53.

37. Fajans SS, Bell GI. MODY: history, genetics, pathophysiology, and clinical decision making. Diabetes Care. 2011;34(8):1878-84.

38. Chapla A, Mruthyunjaya MD, Asha HS, Varghese D, Varshney M, Vasan SK, Venkatesan P, Nair V, Mathai S, Paul TV, et al. Maturity onset diabetes of the young in India - a distinctive mutation pattern identified through targeted next-generation sequencing. Clin Endocrinol. 2015;82(4):533-42.

39. Mohan $V$, Radha V, Nguyen TT, Stawiski EW, Pahuja KB, Goldstein LD, Tom J, Anjana RM, Kong-Beltran M, Bhangale T, et al. Comprehensive genomic analysis identifies pathogenic variants in maturity-onset diabetes of the young (MODY) patients in South India. BMC Med Genet. 2018;19(1):22.

40. Kwak SH, Jung CH, Ahn CH, Park J, Chae J, Jung HS, Cho YM, Lee DH, Kim $\mathrm{Jl}$, Park KS. Clinical whole exome sequencing in early onset diabetes patients. Diabetes Res Clin Pract. 2016;122:71-7.

41. Park SS, Jang SS, Ahn CH, Kim JH, Jung HS, Cho YM, Lee YA, Shin CH, Chae $J \mathrm{H}, \mathrm{Kim} J \mathrm{H}$, et al. Identifying pathogenic variants of monogenic diabetes using targeted panel sequencing in an east Asian population. J Clin Endocrinol Metab. 2019. https://doi.org/10.1210/jc.2018-02397. Epub Apr 12 2019.

42. Shields BM, Hicks S, Shepherd MH, Colclough K, Hattersley AT, Ellard S. Maturity-onset diabetes of the young (MODY): how many cases are we missing? Diabetologia. 2010;53(12):2504-8.

43. Broome DT, Pantalone KM, Kashyap SR, Philipson LH. Approach to the patient with MODY-monogenic diabetes. J Clin Endocrinol Metab. 2021; 106(1):237-50.

44. McDonald TJ, Shields BM, Lawry J, Owen KR, Gloyn AL, Ellard S, Hattersley AT. High-sensitivity CRP discriminates HNF1A-MODY from other subtypes of diabetes. Diabetes Care. 2011;34(8):1860-2.

45. Besser RE, Shepherd MH, McDonald TJ, Shields BM, Knight BA, Ellard S, Hattersley AT. Urinary C-peptide creatinine ratio is a practical outpatient tool for identifying hepatocyte nuclear factor 1-\{alpha\}/hepatocyte nuclear factor 4-\{alpha\} maturity-onset diabetes of the young from long-duration type 1 diabetes. Diabetes Care. 2011;34(2):286-91.

\section{Publisher's Note}

Springer Nature remains neutral with regard to jurisdictional claims in published maps and institutional affiliations.

Ready to submit your research? Choose BMC and benefit from:

- fast, convenient online submission

- thorough peer review by experienced researchers in your field

- rapid publication on acceptance

- support for research data, including large and complex data types

- gold Open Access which fosters wider collaboration and increased citations

- maximum visibility for your research: over $100 \mathrm{M}$ website views per year

At BMC, research is always in progress.

Learn more biomedcentral.com/submission 